\title{
PALABRAS DESDE EL EXILIO
}

\author{
WORDS FROM THE EXILE
}

Laura Branciforte

Universidad Carlos III de Madrid

\section{Resumen:}

En esta ponencia daremos a conocer los sufrimientos de la vida de Flor Cernuda a través de sus propios poemas. Sus versos reflejan una mujer fuerte y luchadora que vivió en una época que no se lo puso fácil. Entre sus poemas destaca Paz por su cercanía y sensibilidad.

\section{Palabras claves:}

Flor Cernuda, Paz, poesía.

\section{Abstract:}

In this conference we will make the sufferings of Flor Cernuda throughout her own poems. Her verses reflect a brave and fighter woman who lived in a time period that did not make the things easy for her. Between her poems Paz stands out because of its closeness and sensitivity.

\section{KEY WORD:}

Flor Cernuda, Paz, poetry. 
El guion de esta comunicación no serán mis palabras, sino aquéllas de una mujer especialmente sus poesías. Se trata de Flor Cernuda, luchadora tenaz y protagonista en primera línea de la Historia española de los años 30, pero en los años sucesivos forzada a permanecer en la retaguardia. No pretendemos en este caso sintonizarnos con un discurso, recientemente tantas veces repetido, tantas veces utilizado en prácticas públicas y privadas, con propósitos más o menos confesables, más o menos de utilidad común; nos referimos al de hacer memoria. Sabemos que la memoria en cuanto tal olvida y debe de olvidar para seguir en su selectiva función ${ }^{1}$ y sabemos también que la objetiva subjetividad del recuerdo hace que tenga para cada uno un valor y un significado distintivo. Por lo tanto, no queremos en esta comunicación ni exhortar al recuerdo, ni aventurarnos en la reconstrucción de una historia que no ostentaría aquella objetividad que a veces, algo injustamente, se le requiere a quien "reconstruye", o por lo menos anhela a reconstruir, el pasado ${ }^{2}$. Nos limitaremos simplemente a dar voz a una mujer siempre silenciada por el incesante, natural e histórico transcurrir del tiempo, cuyos acontecimientos han contribuido de forma indebida a crear este vacío a su alrededor.

Conocimos a Flor Cernuda de forma del todo fortuita, como testigo ocular de las vivencias de otro personaje, de otra mujer a quien ella trató directamente y que nos disponíamos a biografiar. Se trataba de un sujeto fascinante y representativo de la historia de los años treinta, de la fotógrafa italiana Tina Modotti (Branciforte, 2006: 289-309). Esta última y Flor Cernuda se conocieron y coincidieron en las peripecias de la Guerra Civil, cuando Modotti tenía aproximadamente la edad de treinta años y Flor acababa de asomarse a la mayoría de edad. Esperábamos que Flor pudiese contarnos algo de la célebre fotógrafa, dado que la habíamos oído hablar de la artista en una grabación realizada con ocasión de una exposición sobre Modotti³ ${ }^{3}$ A pesar de varios tropiezos, logramos encontrar a Flor en la primavera de 2004, en una residencia de ancianos donde vive aún hoy en día. Inesperadamente nos encontramos frente a una situación imprevista: por un lado, ahí estábamos con nuestra férrea pretensión de reconstruir una biografía, que además es "histórica" (siempre dentro de los límites de la veracidad de esta definición ${ }^{4}$ ); por el otro, esta narración biográfica se iba entrecruzando paulatinamente con una narración auto-biográfica. Este "involuntario", o mejor dicho

1 "Hay que recordar que la memoria no se opone en absoluto al olvido. Los dos términos para contrastar son la supresión (el olvido) y la construcción; la memoria es, en todo momento y necesariamente, una interacción de ambos" (Todorov, 2004: 15-16)

2 "El subjetivismo se basa en el hecho que: la diferencia entre cualquier tipo de acontecimiento y los que juzgamos dignos de la historia es el valor que atribuimos a éstos" (Veyne, 1984: 44.)

3 Se trataba de una conferencia celebrada con ocasión de la exposición sobre la fotógrafa con el título Modotti Fotógrafa, 1993.

4 Siempre y cuando no se interpongan, por ejemplo, White, La Capra, Veyne, Barthes, Bachelard o Feyerabend, cuestionando el criterio formal de la verdad y negando que la ciencia histórica sea el reflejo de una realidad (Cfr. White, 2003). natural, deseo de la entrevistada de narrarse, de contar su propia historia, desbordó nuestro afán biográfico. El descubrimiento y la fascinación por esta otra involuntaria narración autobiográfica que se nos fue desplegando en el seno de una biografía ajena a la primera ${ }^{5}$ y que, sin embargo, resultaba tan interesante como la biografía que era nuestro primer objetivo, es lo que más nos sorprendió y que ahora nos anima a hablar, no de su vida sino de su misma autobiografía a través de sus poemas.

Es una poesía, Paz, la que nos acercó a la sensibilidad y a la historia de esta mujer y a la de miles de otros hombres y mujeres que estuvieron a su lado y que ahora, como ella misma sostiene, son parte de sus memorias. Frente a la frialdad del sitio en el que vive, al blanco de las paredes, a los pasillos sin fin, a la homogeneidad de los ambientes, este poema distingue netamente el umbral de la habitación de Flor. Un enorme edificio blanco y aséptico, construido en época franquista, es el lugar donde paradójicamente se hospeda, ella, que perteneció a las Juventudes Socialistas y más tarde entró a formar parte del Partido Comunista de España, y que trabajó durante la guerra el en Comité Ejecutivo del Socorro Rojo Internacional ${ }^{6}$ (S. R. I.) (Entrevista a Flor Cernuda, 17-0404). Desde la soledad de esta habitación y de su existencia actual, la poesía surge como su compañera predilecta, si bien la atmósfera que la envuelve nos provoca la sensación de que ni siquiera la poesía puede colmar el vacío y que la memoria aquí no es otra cosa que sinónimo de olvido. Se vislumbran claramente, entre las líneas de su poema, palabras de cansancio merecido y buscado, de esperanza vulnerable, aunque ardientemente anhelada, palabras de solidaridad y de desconfianza:

He querido atar la PAZ con mis cabellos, para que no se

marche: mecerla entre mis brazos: abrigarla con un beso, pero esto es poca cosa.. La PAZ vuela más alto y no

se deja: no tiene confianza jtodavía!: conoce la traición, y anda remisa, desconfiada... Quiero, con la ayuda de tus manos, conseguir la PAZ

para los siglos

El poema Paznos introduceen la unicidad de su ambiente. Elinterior desu habitación corresponde a la imagen que de ella nos acababa de dar su poesía. Aquí, además de sus palabras, son los libros y las fotografías las que nos siguen introduciendo en la vida de esta dulce y firme existencia y en la realidad de su historia que es a mismo tiempo privada y colectiva. En un rápido travelín pasa de la fotografís mismo tiempo priva y colocías de un hombre en divisa militar -su hermano pequeño, que murió en el parque de la "Casa de Campo"- a la foto de la conflictiva figura del mítico Comandante Carlos Contreras (Vidali, 1983) para llegar, finalmente, a la imprescindible foto de Fidel Castro y una última en la que se ve a Flor retratada junto a la Pasionaria. Estas "miradas fotográficas" gracias a las cuales, como diría Susan Sontang, se tiene "la impresión de que podemos contener el mundo entero en la cabeza, como una antología de imágenes" (Sontag, 2006: 15), se acompañan, como si fueran un pie

5 Algo parecido nos sugiere el título la novela Autobiografie altrui. Poetiche a posteriori de Antonio Tabucchi (2003)

6 Empezó a trabajar en el Socorro Rojo Internacional a la edad de 17 años en su pueblo de origen Villacañas en la provincia de Toledo. Desde allí fue enviada a Valencia por la misma organización hasta que, con el estallido de la Guerra Civil, entró en el Comité Ejecutivo del S. R. I. en Madrid. 
de foto o un comentario, con las poesías que Flor dedica a ese mundo, un mundo que ahora captura a través de unos retratos poéticos embebidos, no cabe duda, de un valor más semántico que poético. Dedica a Dolores Ibarruri, en el centenario de su nacimiento, el texto "La llamaron pasionaria", en el que percibimos su deseo de hacer de esta figura una memoria ejemplar y útil para el futuro. Querría en tu honor, seguir hablando de ti y de tus enseñanzas, de tu sencillez y fortaleza, para decir a las mujeres del mundo de hoy que, hay que seguir la lucha por el mismo camino que abriste, que nada nos darán graciosamente que hay que luchar para que nos os quiten el trabajo y para conseguir que nuestros hijos no sean pasto de la hierba que mata, sino que sean mejores mujeres y hombres de mentes sanas y manos tendidas a la Paz. Y en tu nombre, hoy, en esa primavera de sus cien años nacía, digo con el poeta Miguel Hernández, la juventud siempre empuja, la juventud siempre vence y la salvación de España, de su juventud depende. Ojala la juventud, nuestra juventud de hoy, tome en consideración que es tarde cada día que pasa sin trabajar, porque el trabajo es necesario para vivir en paz y la cultura para que la palabra sea legible y limpia: y el amor (Cernuda 1997). De sus poemas brotan pabras de enorme convicción, amor por libertad y respeto por poemas brotan palabras de enorme conviccion, amor por libertad y respeto por la humanidad, como vemos en éste que se acaba de leer y tambien en algunos versos dedicados a la memoria de García Lorca, como el poema "Dolora".

Recordando a García Lorca

En aquellas horas de no sé que día

o de qué madrugada

en ese duermevela

de las horas cansadas, escuché

allá lejos, campanillas dobladas

de plata, que sonaban terribles

con clamor de llanto del alba... (Cernuda, 1998)

Sus narraciones y poemas parecían transformar en realidad tangible algunos acontecimientos históricos fundamentales y que hasta el momento simplemente eran historias leídas. Según proseguía enseñándonos estos poemas (Cernuda, 1992) y hablándonos de tantas cosas que tenían que ver con la biografía que estábamos escribiendo, sus recuerdos comenzaron a convertirse en un nuevo sujeto de nuestra investigación. Las palabras orales y escritas de esta mujer ya habían adquirido otro significado. Flor era la "toledana", así apodada por el comandante Carlos Contreras por estar sus orígenes en un desconocido pueblo de la Mancha (Villacañas), como ella misma cuenta con un cierto tono de orgullo. La ironía y el sarcasmo de Flor la acompañan en todo momento, también en esta situación de exilio forzado en la cual siente que está viviendo; en un ambiente que no le es propio, "donde -como comenta ella misma- la gente se dedica sólo a chismorrear". Critica, protesta a través de sus de sus $\operatorname{cartas}^{7}$ y poemas, consciente de ejercer en todo momento y de manera plena su derecho al uso público de la escritura. En los años ochenta escribía poemas de protesta en contra de Pinochet, al que se dirigía sarcástica y ferozmente:

no llegas ni a Pinocho muñeco gracioso y divertido.

7 Como por ejemplo las que apareció en El País, Cernuda, F. “La clave del Marxismo”, El País, 16 de noviembre de 1979
Eres como un pelele, linfatico y grosero embebido en uniforme rutilante planchado y, con colgajos de medallas

ganadas, en horribles batallas de sangre, contra el pueblo

$[\ldots]$

$Y$ con ¡NERUDA! ¿que hiciste con NERUDA?

¡De qué forma te hirió su poesía!

También le quitaste la vida

arrasando su casa y quemando las letras que en sus libros

saltaban de las llamas y recorrían el mundo de las gentes

que siguen, de ese pueblo de CHILE, su gran drama (Cernuda, “Derechos humanos

de un general").

Una vez más pide la paz en un poema de denuncia en memoria de Olof Palme. De forma tajante, incisiva y firme, con una escritura que refleja el coraje y coherencia de esta mujer.

¿Quién es quien mata la Paz...?

Que nadie diga: es un loco

Están matando al Paz

Un puñado de ambiciosos y cobardes

Amparados en poderes y obsesiones.

Ya no les basta remover el miedo

Preparar las guerras y, después,

Aprestarse a salvar los pueblos (Cernuda, 1986).

Éstos son sólo algunos de los versos y algunos de los poemas de esta mujer de una apariencia física grácil y frágil, que esconde dentro de sí una fuerza inusitada para sus 90 años de difícil existencia ${ }^{8}$. Los hechos pasados parecen haberla fortalecido en su capacidad de luchar por el respeto de los derechos civiles de todos ${ }^{9} \mathrm{y}$ suyos hoy en día. La fuerza de sus palabras y de estos últimos versos que inmediatamente traemos a colación es una vez más el reflejo de una mujer cuya biografía se puede reconstruir perfectamente a través de sus poemas. Recientemente Flor admitía que "sólo ahora quizás es un poco menos esperanzadora y optimista de aquel entonces cuando, en 1936, a los 18 años de edad, se había encontrado con entusiasmo y una pizca de inconciencia a enfrentarse con un mundo y una guerra parra ella aún más desconocidos" (Entrevista a Flor Cernuda, 11-04-06). La misma mujer que en la celebración del $65^{\circ}$ aniversario de la llegada a España de las Brigadas Internacionales pronunciaba con fuerza algunos

8 Víctima de las cárceles franquistas y de sucesivas persecuciones durante la dictadura, la vida de Flor no fue fácil, como no lo que fue para muchos al final de la guerra. Como ella misma nos cuenta, "fueron por mí a mi casa, a Villacañas, donde me estaban esperando dos personas del pueblo con la boina calada y una recortada". Vivió la experiencia de las detenciones durante los años de la dictadura; fue mandada 2 ó 3 veces a Gobernación, lo que ella misma llama el "Palacio de las torturas", "la que llaman ahora" -añade- "la Real Casa de Correos, donde los políticos hoy en día
toman café" (Entrevista a Flor Cernuda, 16-05-04).

9 A la muerte de Franco, Flor sigue siendo cada vez más activa: en 1975 trabaja en la reapertura del "Club de Amigos de la UNESCO" que, según ella misma afirma, es "para la cultura y la educación". El respeto de los derechos fue lo que la empujo a fundar la "Asociacion pro Derechos Humanos" (Entrevista a Flor Cernuda, 16-05-04). 
versos que había escrito en su honor: “QQue no sabes quiénes eran? Que sí, pero que no... que tu flamante juventud no atiende a cuentos ni a batallitas" (Gomar, 2001: 01) Apéndice

\section{PAZ}

Por la PAZ volaron miles de palomas

de todos los colores.

Por la PAZ brotaron manantiales de agua cristalina

en los páramos más yermos.

Por la PAZ se abrieron los volcanes,

anzando llamas de fuego

que habita en el centro del Planeta.

Por la PAZ corrió sangre

empapando la tierra.

Por la PAZ he gritado en el destierro,

y el eco me ha devuelto millones de sonidos

que clamaban amo

Por la PAZ los hombres siguen arrastrando cadenas.

Por la PAZ lucha mi libertad,

y la de mis hermanos.

Por la PAZ mis cabellos castaños se volvieron de plata,

y mis manos temblorosas

se unieron a las tuyas

en cadena de solidaridad.

Por la PAZ rezo más fuerte mis canciones de amor

Hay que conseguir la PAZ

Para los niños que llegarán mañana.

He querido atar la PAZ con mis cabellos, para que no se marche: mecerla entre mis brazos: abrigarla con un beso, pero esto es poca cosa... La PAZ vuela más alto y no se deja: no tiene confianza jtodavía!: conoce la traición, y anda remisa,

desconfiada...

Quiero, con la ayuda de tus manos, conseguir la PAZ para los siglos.

\section{REFERENCIAS BIBLIOGRÁFICAS}

Branciforte, L., "Tina Modotti: una intensa vida entre Europa y América”, en Stvdia Histórica, Salamanca, Historia Contemporánea, vol. 24, 2006, Ed. Universidad de Salamanca, pp. 289-309.

Cernuda, F. “La clave del Marxismo", El País, 16 de noviembre de 1979.

Gomar, J. J., “Vuelta a la batalla del Jarama”, El Mundo, sección "el Cultural” de Madrid, 28 de octubre de 2001, p. 1.

Sontang, S., Sobre la fotografía, Madrid, Santillana, 2006.

Tabucchi, A., Autobiografie altrui. Poetiche a posteriori, Milán, Feltrinelli, 2003.

Tina Modotti Fotógrafa, (1993), Exposición, Obra Social y Cultural de la Caja de Ahorros de Asturias, Casa de América, Madrid.

Todorov, T., Los abusos de le memoria, Barcelona, Paidós Asterisco, 2004.

Veyne, P., Cómo se escribe la historia. Focault revoluciona la historia, Madrid, Alianza Universidad, 1984.

Vidali, V., Comandante Carlos, Roma, Editori Riuniti, 1983.
White, H., El texto histórico como artefacto literario, I.C.E. de la Universidad Autónoma de Barcelona, Paidós, 2003.

\section{Poesías de Flor Cernuda}

"La llamaron pasionaria", 31 de marzo de 1997.

"Dolora", 31 de diciembre de 1998.

"Derechos humanos de un general"

"Cumbre de las Américas", 24 de julio de 1992.

“A la memoria de Olof Palme, Lágrimas por la paz", 2 de marzo de 1986, Revista Caum.

Entrevistas

Entrevista realizada a Flor Cernuda el 17 de Abril de 2004, Madrid.

Entrevista realizada a Flor Cernuda el 16 de Mayo de 2004, Madrid.

Entrevista realizada a Flor Cernuda el 11 de abril de 2006, Madrid. 